6. Про внесення змін до деяких законодавчих акті України щодо впровадження Єдиного реєстру осіб, засуджених за злочини проти статевої свободи та статевої недоторканості малолітньої особи, та посилення відповідальності за злочини, вчинені проти статевої свободи та статевої недоторканості малолітньої особи: Закон України від 19.12.2019 p. № 409-IX. URL: https://zakon.rada.gov.ua/laws/show/ 409-20\#Техt (дата звернення: 02.09.2020).

7. Хмыров А.А. Косвенные доказательства. Москва: Юридическая литература, 1979. 184 с.

DOI https://doi.org/10.30525/978-9934-588-92-1-91

\title{
ЩОДО ПРОБЛЕМНИХ ПИТАНЬ ВИЗНАЧЕННЯ ПРАВОВОЇ КВАЛІФІКАЦІЇ ВЧИНЕНОГО КРИМІНАЛЬНОГО ПРАВОПОРУШЕННЯ ТА УЗГОДЖЕНОГО ПОКАРАННЯ ПРИ УКЛАДАННІ ТА ЗАТВЕРДЖЕННІ УГОД
}

\author{
Сіроткіна М. В. \\ кандидат юридичних наук, \\ здобувач кафедри кримінального процесу та криміналістики \\ Інституту права \\ Київського начіонального університету імені Тараса Шевченка \\ м. Київ, Украӥна
}

При укладанні угод про примирення та визнання винуватості суб'єкти їх укладення визначають правову кваліфікацію вчиненого кримінального правопорушення, за яке підозрюваний чи обвинувачений буде нести відповідальність (ст.ст. 471, 472 КПК України). У цьому аспекті необхідно вказати на відповідальність, яку покладено на суд кримінальним процесуальним законом, оскільки саме обов'язком суду $\epsilon$ встановлення відповідності правової кваліфікації правопорушення викладеним в угоді фактичним обставинам вчинення кримінального правопорушення.

Існує загроза того, що прокурор або потерпілий, з одного боку, та підозрюваний/обвинувачений - 3 іншого, досягнувши угоди про визнання винуватості або примирення, не позбавлені можливості викласти в тексті угоди обставини кримінального правопорушення, зазначивши при цьому зовсім іншу правову кваліфікацію вчиненого 
правопорушення 3 метою досягнення можливості укладення такої угоди. Отже, під час здійснення судового розгляду відповідної угоди судам потрібно ретельно перевіряти правову кваліфікацію вчиненого правопорушення, відображену в угоді, 3 метою недопущення зловживання використання сторонами процесу даного інституту угод у кримінальному провадженні.

Так, ухвалою Солонянського районного суду Дніпропетровської області від 9 квітня 2013 року по справі № 192/584/8713-к, провадження № 1-кп/192/42/13, було відмовлено в затвердженні угоди про визнання винуватості, укладеної між старшим прокурором прокуратури Дніпропетровської області та обвинуваченою ОСОБА_1. 3 підстав встановлення в ході судового розгляду суперечності стосовно правової кваліфікації вчиненого правопорушення, оскільки в угоді про визнання винуватості було зазначено, що ОСОБА_1 підозрюється у вчиненні кримінального правопорушення, передбаченого ч. 1 ст. 366 КК України, що виразилося у видачі службовою особою завідомо неправдивих документів та внесенні до них завідомо неправдивих відомостей, тоді як у мотивувальній частині обвинувального акта вказано, що дії ОСОБА_1 виразилися у складанні завідомо неправдивих офіційних документів [1, с. 341$]$.

Окрім того, в частині, що стосується правової кваліфікації вчиненого обвинуваченим діяння, може бути допущена неправильна правова кваліфікація кримінального правопорушення, не лише яке $\epsilon$ більш тяжким ніж те, щодо якого передбачена можливість укладення угоди, а й більш м'яким у непередбачених законом випадках.

Так, вироком Бродівського районного суду Львівської області від 09 листопада 2017 року затверджено угоду про визнання винуватості, укладену 09 жовтня 2017 року між начальником Бродівського відділу Радехівської місцевої прокуратури та О. Цим вироком О. визнано винуватим у вчиненні злочину, передбаченого ч. 1 ст. 309 КК та призначено йому узгоджене сторонами покарання у виді штрафу в розмірі п’ятдесяти неоподатковуваних мінімумів доходів громадян, що становить 850 грн. А також, згідно другого пункту резолютивної частини, О. звільнено від кримінальної відповідальності на підставі ст. 2 Закону України «Про амністію у 2016 році», а кримінальне провадження закрито. Нагадаємо, що Законом України «Про внесення змін до Закону України від 02 червня 2011 року № 3465-VI «Про застосування амністії в Україні» та інших законодавчих актів» до статей 44, 86 Кримінального кодексу України були внесені відповідні зміни, згідно яких, можливість звільнення особи від кримінальної відповідальності внаслідок застосування до неї закону України про амністію, виключається. 
Прокурор, керуючись п. 2 ч. 4 ст. 394 КПК оскаржив дане судове рішення до суду апеляційної інстанції з підстав, що місцевий суд фактично призначив обвинуваченому менш суворе покарання, ніж узгоджене сторонами угоди. У свою чергу Апеляційний суд ухвалою закрив апеляційне провадження за апеляційною скаргою прокурора на вказаний вирок суду першої інстанції.

Зазначена ухвала суду апеляційної інстанції стала предметом касаційного оскарження прокурором. Колегія суддів ККС ВС 3 доводами касаційної скарги частково погодилася і вказала, що за загальним правилом, у випадку наявності підстав для звільнення від кримінальної відповідальності, 3 огляду на те, що інститут угод у кримінальному провадженні, як і інститут призначення покарання у тому числі з урахуванням його особливостей у випадку затвердження угоди (ч. 5 ст. 65 КК) жодним чином (як в матеріальному, так і в процесуальному аспектах) не кореспондуються з інститутом звільнення від кримінальної відповідальності, $є$ взаємовиключними та потребують розмежування, суд має згідно з п. 3 ч. 7 ст. 474 КПК відмовити у затвердженні угоди та звільнити особу від кримінальної відповідальності. У цьому аспекті також варто зважати на змістовне навантаження ч. 3 ст. 314 КПК, яка, передбачаючи відокремлений перелік судових рішень, які суд може прийняти у підготовчому судовому засіданні (окремі з яких по своїй суті є завершальними для судового провадження у суді першої інстанції - затвердження угоди вироком суду (п. 1 ч. 3) та закриття провадження у зв'язку зі звільненням особи від кримінальної відповідальності ухвалою суду (п. 2 ч. 3) та спричиняють різні правові наслідки), визначає межі розсуду суду в обсязі наведених в ній процесуальних можливостей. Підміна одного рішення іншим не допускається.

Поряд 3 тим, варто зазначити, що відповідно до ст. 472 КПК «узгоджене покарання та звільнення від його відбування 3 випробуванням (якщо такі домовленості мали місце так сторони дійшли згоди)» $\epsilon$ обов'язковими складовими змісту угоди, яке, у випадку затвердження останньої, згідно закріпленої уст. 475 КПК імперативної вимоги через використання у нормі словосполучення «призначає узгоджену сторонами міру покарання», має бути призначене судом. Вжите ж у п. 2 ч. 4 ст. 394 КПК формулювання «призначення судом покарання, менш суворого, ніж узгоджене сторонами угоди», як підстави для оскарження прокурором вироку на підставі угоди про визнання винуватості, свідчить, що дана норма кореспондує із ст. 475 КПК, і є гарантією ії реалізації.

Враховуючи вищевикладене, оскільки суд ухвалив вирок на підставі угоди про визнання винуватості, який за своїм змістом $\epsilon$ 
обвинувальним (ст. 373 КПК), вказав про призначення узгодженої сторонами міри покарання, одночасно звільнивши особу від кримінальної відповідальності, чим знівелював та, відповідно, не реалізував укладену угоду як таку (за своїм змістом укладення угоди між сторонами свідчить про узгодження умов відповідальності, виконання яких при ії затвердженні судом $є$ обов'язковими для сторін та тягне певні правові наслідки в разі їх невиконання), тобто прийняв рішення, яке не передбачене КПК [2]. Такі випадки у практичній діяльності непоодинокі [3, с. 148].

Слід звертати увагу на те, що домовленості сторін угоди при узгодженні покарання не мають виходити за межі загальних та спеціальних засад призначення покарання, встановлених законом України про кримінальну відповідальність. [4].

Також підтримуємо думку I.А. Тітка 3 приводу того, що істотним недоліком не лише 3 позиції конструювання тексту кримінального процесуального закону, а й з погляду дієвості практичного застосування КПК у частині забезпечення приватних інтересів учасників кримінального провадження є прогальність ст. 42 КПК, яка встановлює загальний перелік процесуальних прав підозрюваного, обвинуваченого, але не містить вказівки на право укласти (ініціювати) угоду про примирення або про визнання винуватості [5, с. 21]. Підозрюваний (обвинувачений) таке право має і воно $є$ досить важливим як для нього, так і для інших учасників кримінального провадження. Пропонуємо частину 3 статті 42 КПК України доповнити пунктом 19 та викласти його у наступній редакції: «укласти угоду про визнання винуватості та про примирення із потерпілим у передбачених законом випадках».

\section{Література:}

1. Дирдін М. Є., Кукуюк О. В. Практичні аспекти кримінального провадження на підставі угод. Міжнар. юрид. вісник: збірник наук. праць Наи. ун-ту держ. податкової служби Украӥни. 2016. Вип. 1 (3). C. 29-34.

2. Постанова Верховного Суду від 16 жовтня 2018 року у справі № 439/1344/17, провадження № 51-6922 км 18 . URL https://protocol.ua/ua/institut_ugod_u_kriminalnomu_provadgenni_godnim_ chinom.

3. Темніков О. В. Про деякі практичні переваги та законодавчі вади застосування інституту угод в кримінальному провадженні. Юридичний бюлетень. 2016. Вип. 3. С. 139-152.

4. Постанова пленуму Вищого спеціалізованого суду України 3 розгляду цивільних і кримінальних справ від 11.12.2015 р. № 13 «Про 
практику здійснення судами кримінального провадження на підставі угод». URL : https://zakon5.rada.gov.ua/laws/show/v0013740-15.

5. Тітко I. А. Нормативне забезпечення та практика реалізації приватного інтересу в кримінальному процесі України : автореф. дис. ... докт. юрид. наук : 12.00.09. Нац. юрид. акад. імені Ярослава Мудрого ; Харків, 2016. 36 с.

DOI https://doi.org/10.30525/978-9934-588-92-1-92

\title{
ОСОБЛИВОСТІ ПРАВОСУДДЯ, ДРУЖНЬОГО ДО ДИТИНИ (КРИМІНАЛЬНИЙ АСПЕКТ)
}

\author{
Хмелевська Н. В. \\ кандидат юридичних наук, \\ доиент кафедри кримінального права та проиесу \\ Хмельницького університету управління та права \\ імені Леоніда Юзькова \\ м. Хмельницький, Украӥна
}

Актуальним питанням в Україні є здійснення правосуддя за участю дитини. Найбільш складним $є$ притягнення неповнолітніх до кримінальної відповідальності. Важливим в цьому є дотримання всіх особливостей, які існують задля найшвидшого виведення дитини із конфлікту з законом.

Одним із найважливіших моментів $є$ дотримання швидкого розгляду кримінальних проваджень щодо неповнолітніх. Кожна особа (незалежно від віку) відповідно до ст. 6 Конвенції про захист прав людини і основоположних свобод має право на розгляд іiі справи протягом розумного строку. Водночас у випадку кримінального провадження щодо неповнолітнього застосуванню підлягає більш сувора вимога - невідкладний розгляд. На міжнародному рівні існує консенсус із приводу того, що для дітей, які перебувають у конфлікті із законом, період часу між вчиненням злочину й остаточним реагуванням на цей вчинок має бути якомога коротшим. Чим триваліший $є$ цей період, тим більшою $є$ ймовірність того, що захід реагування втратить свій позитивний і виховний вплив, і тим більше шкоди буде завдано репутації дитини. 3 часом неповнолітній особі все важче, а іноді й неможливо, логічно і психологічно пов'язати 